\title{
KEBIJAKAN PEMERINTAH DALAM RANGKA MEWUJUDKAN NEGARA KESEJAHTERAAN
}

\author{
Darmini \\ STMIK Mataram \\ darmini.cc@gmail.com
}

\begin{abstract}
Abstrak - Penelitian ini bertujuan untuk mengetahui apa sebenarnya peran pemerintah yang diamanatkan negara untuk rakyatnya. Kebijakan Pemerintah sebagai suatu kebijakan publik merupakan kebijakan yang menjadi wewenang pemerintah dan diberikan Negara sesuai dengan amanat Konstitusi. Untuk melaksanakan kebijakan dimaksud, pemerintah telah diberikan alat kelengkapan untuk mengeksekusi kebijakan, baik dalam bentuk dukungan anggaran, perangkat pemaksa, sumber daya manusia, instrumen hukum, pengelolaan sumber daya alam, yang dilaksanakan sesuai dengan peraturan per-undang-undangan. Untuk melaksanakan kebijakan pemerintah, telah disusun sistem perencanaan yang komprehensif dengan memperhatikan kemampuan ekonomi makro, dan kemampuan fiskal Negara. Telah disusun Rencana Pembangunan Menengah Nasional siklus 5 tahunan dan Rencana Kerja Pemerintah dan Rencana Strategis Kementerian / Lembaga untuk melaksanakan Konstitusi yaitu terwujudnya Negara Kesejateraan. Berbagai indikator Kesejahteraan telah dirumuskan oleh Badan Pusat Statistik sebagai lembaga pemerintah yang kredibel, dan terlihat progress yang telah dicapai untuk mewujudkan Negara Kesejahteraan. Hasilnya menunjukkan ada peningkatan, namun lambat dan kurang signikan jika dibandingkan dengan dukungan anggaran belanja yang disediakan pemerintah. Masih tingginya angka kemiskinan $11,22 \%$ dengan Gino rasio 0,41 merupakan indikasi bahwa tingginya angka kemiskian tersebut ( sekitar 28 juta jiwa), dikuti kesenjangan pendapatan yang semakin lebar, untuk terjadinya (pemicu) masalah sosial, konflik sosial dan kerawanan-kerawanan yang akan melebar ke wilayah politik, dan integritas NKRI.
\end{abstract}

Kata Kunci: kebijakan, Pemerintah, Kesejahteraan

\section{Latar Belakang}

Kebijakan Pemerintah tentu tidak terlepas dari peran pemerintah yang diamanatkan negara untuk rakyatnya. Pemerintah adalah instrumen negara yang ditugaskan untuk melaksanakan Pemerintahan sesuai dengan Konstitusi Negara. Maka itu "pemerintah" disebut juga sebagai Penyelenggara negara dan harus mengawal dan melaksanakan idiologi negara. Idiologi negara Indonesia adalah tentu mewujudkan Negara Kesejahteraan (Welfare State) sebagaimana tercantum dalam Pembukaan UUD 1945 khususnya yang menyangkut masalah tujuan negara Indonesia, pada intinya dapat dirumuskan sebagai " memajukan kesejahteraan umum dan mencerdaskan kehidupan bangsa yang didasarkan pada prinsip keadilan sosial bagi seluruh rakyat Indonesia". Tujuan yang dimuat di dalam pembukaan tersebut kemudian di dalam batang tubuh UUD 1945 dituangkan dalam berbagai ketentuan yang menyangkut kesejahteraan rakyat. Tugas utama pemerintah sebagai penyelenggara negara, setidak-tidaknya ada tiga hal yaitu : pertama, sebagai Administrator Pemerintahan; kedua, sebagai Administrator Pembangunan dan ketiga , sebagai Administrator
Kemasyarakatan. Diharapkan dengan tugas utama tersebut, maka upaya mewujudkan kesejahteraan dimaksud diselenggarakan dengan sistem pemerintahan yang baik, pembangunan dilaksanakan dengan tertib , prosedural, jujur, adil, efektif, efisien, dan dengan mengajak dan berperan sertanya masyarakat secara luas. Oleh karena itu agar penyelenggaraan pemerintah dapat dilaksanakan dengan baik menurut Kavin Dayoh ada 9 karakteristik dan 9 azas yang perlu dijadikaan rujukan. 9 karakeristik tersebut adalah, pertama, partisipasi masyarakat; kedua, aturan hukum; ketiga, transparansi; keempat, sikap responsif; kelima, berorientasi pada consensus; keenam, kesetaraan/kesederajatan; ketujuh, efektifitas dan effisien; kedelapan, akuntabilitas; kesembilan, visi strategis; dan adapun kesembilan azas dimaksud adalah, pertama, asas kepastian hukum; kedua, asas tertib penyelenggaraan negara; ketiga, asas kepentingan umum; keempat, asas keterbukaan; kelima, proporsionalitas; keenam, asas profesionalitas; ketujuh, asas akuntabilitas; asa efisiensi dan kesembilan asas efektifitas. 


\section{Kajian Pustaka}

Kebijakan pemerintah adalah suatu bentuk kebijakan publik. Karena pemerintah adalah lembaga negara yang diberikan kewenangan yang luas oleh konstitusi untuk membuat kebijakan dalam menyelenggarakan negara sesuai dengan ketentuan peraturan dan perundang-undangan yang berlaku. Pemahaman kebijakan pemerintah sebagai kebijakan publik, telah banyak diuraikan oleh para ahli. Beberapa nama sering kita kutip jika kita berbicara tentang kebijakan publik, antara lain, David Easton; Carl J. Friedrick; Thomas R. Dye; James F. Anderson. Menurut David Easton, "Public policy is the authoritative of values for the whole society" Kebijakan publik adalah pengalokasian nilai nilai secara sah/paksa kepada seluruh masyarakat. Adapun kebijakan publik sebagaimana yang dirumuskan oleh Easton (dalam Thoha 2002:62-63) merupakan alokasi nilai yang otoritatif oleh seluruh masyarakat. Akan tetapi, hanya pemerintah sajalah yang berbuat secara otoritatif untuk seluruh masyarakat, dan semuanya yang dipilih oleh pemerintah untuk dikerjakan atau untuk tidak dikerjakan adalah hasil-hasil dari nilai-nilai tersebut. Sedangkan Friedrick merumuskan sebagai nerikut; "Public policy is the proposed course of action of a person, group, of goverment within a given environment providing obstacles and opportunities which the policy was proposed to utilize and overcome in an effort to reach a goal or realize an objective or purpose" intinya adalah kebijakan publik merupakan serangkaian tindakan yang diusulkan seseorang, kelompok, atau pemerintah dalam suatu lingkungan tertentu dengan menunjukkan hambatan - hambatan dan kesempatan-kesempatan terhadap pelaksanaan usulan kebijakan tersebut dalam rangka mencapai tujuan tertentu. Yang lebih simpel dan paling sering dirujuk adalah pendapat Thomas R. Dye yaitu, "Public policy is whatever governments choose to do or not to do" Kebijakan publik adalah apa saja yang dipilih oleh pemerintah untuk dilakukan atau untuk tidak dilakukan. Kebijakan publik adalah kebijakan-kebijakan yang dikembangkan oleh badan-badan dan pejabat-pejabat pemerintah. Pendapatan Anderson cenderung mengacu pada permasalahan teknis dan administratif saja. Anderson juga menyatakan bahwa kebijakan publik bersifat positif (merupakan tindakan pemerintah mengenai suatu masalah tertentu) dan bersifat negatif ( keputusan pejabat pemerintah untuk tidak melakukan sesuatu). Kebijakan publik yang positif selalu yang berdasarkan pada peraturan perundang- undangan tertentu yang bersifat memaksa (otoritatif). Dari berbagai pendapat diatas, yang menurut hemat kami saling melengkapi, dapat dimaknai bahwa Kebijakan Publik dibuat dalam kerangka untuk memecahkan masalah dan untuk mencapai tujuan serta sasaran tertentu yang diinginkan. Dalam konteks kesejahteraan, tentu kebijakan publik yang dilakukan pemerintah untuk mencapai tujuan serta sasaran dalam mewujudkan kesejahteraan masyarakat, dengan indikatorindikator Kesejahteraan yang telah ditetapkan lebih dahulu. Kebijakan publik sebagai suatu kebijakan pemerintah adalah keputusankeputusan yang mengikat bagi orang banyak pada tataran strategis atau bersifat garis besar yang dibuat oleh pemegang otoritas publik/pemerintah. Kebijakan pemerintah sebagai suatu keputusan yang mengikjat publik maka haruslah dibuat oleh otoritas politik, yakni mereka yang menerima mandat dari publik atau orang banyak umumnya melalui suatu proses pemilihan untuk bertindak atas nama rakyat banyak.

\section{Metode Penelitian}

Penelitian ini tergolong penelitian hukum normatif dan empirik yang mengkaji bahanbahan hukum sekaligus efektifitasnya di lapangan (law in action).

Dalam penelitian normatif dipelajari bahan hukum primer dan bahan hukum sekunder. Yang dimaksud dengan bahan hukum primer adalah bahan hukum yang bersifat mengikat yang diperoleh dari peraturan perundangundangan. Sedangkan yang dimaksud dengan bahan hukum sekunder adalah bahan hukum yang menjelaskan bahan hukum yang diperoleh dari buku-buku atau literatur-literatur yang relevan dengan masalah yang dibahas.

Dalam penelitian empirik dipelajari data primer dan data sekunder. Data primer adalah data yang diperoleh dari hasil wawancara di lapangan. Adapun informasi atau wawancara ini dilakukan dengan pihak-pihak yang terkait. Sedangkan data sekunder adalah data yang diperoleh melalui studi pustaka dengan mempelajari berbagai buku dan tulisan yang berhubungan dengan peraturan perundangundangan.

\section{Hasil dan Pembahasan}

a. Implementasi Kebijakan Pemerintah

Dalam implementasi untuk melaksanakan Konstitusi UUD 1954, sebagai negara kesejahteraan, maka pemerintah telah menerbitkan berbagai peraturan perundang- 
undangan agar target setting yang ingin dicapai dapat dilaksanakan oleh penyelenggaran negara yaitu Pemerintah dengan perangkat birokrasi dan keterlibatan seluruh masyarakat. Indikator Kesejahteraan dan Progres. Ada 7 indikator utama kesejahteraan yang harus dilaksanakan pemerintah sebagai negara kesejahteraan, dan perlu dilihat pencapaiannya sampai saat ini sesuai dengan rencana-rencana pembangunan yang didokumenkan dalam Rencana Pembangunan Jangka Menengah (5 tahun) dan Rencana Kerja Pemerintah yang disiapkan setiap tahunnya. Untuk urusan Kependudukan, telah ada Undang-Undang Nomor 24 tahun 2013 tentang Perubahan atas Undang-Undang Nomor 23 tahun 2006 tentang Administrasi Kependudukan; urusan Kesehatan ada Undang-Undang Nomor 36 Tahun 2009 tentang Kesehatan, yang merupakan pengganti UU Nomor 23 Tahun 1992 tentang Kesehatan; urusan Pendidikan telah ada Undang-Undang Nomor 20 Tahun 2003 tentang Sistem Pendidikan Nasional; demikian juga sudah ada Undang-Undang Nomor 13 Tahun 2003 tentang Ketenagakerjaan; untuk urusan Pangan terkait Taraf dan Pola Konsumsi ada Undang-Undang Nomor 18 Tahun 2012 tentang Pangan; urusan Perumahan telah diterbitkan Undang-Undang Nomor 1 Tahun 2011 tentang Perumahan dan Kawasan Pemukiman, dan terkait dengan kesejahteraan sosial dan kemiskinan diatur dalam Undang-Undang Nomor 11 Tahun 2009 tentang Kesejahteraan Sosial dan UndangUndang Nomor 13 Tahun 2011 tentang Penanganan Fakir Miskin. Terkait Jaminan Sosial telah diterbitkan Undang-Undang Nomor 40 Tahun 2004 tentang Sistem Jaminan Sosial Nasional, dan Undang-Undang Nomor 24 Tahun 2011 tentang Badan Penyelenggara Jaminan Sosial. Tentunya sebagai tindak lanjut dan penjabaran dari Undang-Undang tersebut diatas, telah diterbitkan puluhan Peraturan Pemerintah , Peraturan Presiden, Peraturan Menteri sebagai implementasi teknis dari amanat Konstitusi sebagai Negara Kesejahteraan. Dengan adanya seperangkat aturan pelaksanaan sebagai implementasi amanat Konstitusi, baik berupa peraturan pemerintah, peraturan presiden, keputusan presiden, instruksi presiden, peraturan menteri, keputusan menteri, peraturan daerah (Perda) propinsi/kabupaten/kota, peraturan gubernur, instruksi gubernur, peraturan bupati/walikota, instruksi bupati/walikota, berbagai pedoman yang diterbit oleh Direktur Jenderal kementerian terkait, keputusan-keputusan
SKPD merupakan instrumen implementasi yang sudah ada dan menjadi acuan dalam pelaksanaan dilapangan. Dari sisi perencanaan telah diatur dalam UndangUndang Nomor 25 tahun 2004 tentang Sistem Perencanaan Nasional, dan ada undangundang yang menetapkan rencana pembangunan jangka panjang yaitu UU Nomor 17 Tahun 2007, tentang RPJP 20052025. Dari UU SPN maka mekanisme perencanaan dilanksanakan dengan sisem yang baik. Dalam menyusun perencanaan tersebut dilengkapi juga dengan pendekatan partisipasi masyarakat, pendekatan buttom-up dan pendekatan top-down. Untuk mengatur Tata Cara Penyusunan Rencana Pembangunan Nasional, diterbitkan Peraturan Presiden Nomor 40 Tahun 2006. Untuk menopang sistem perncanaan tersebut, maka perlu didukung dengan payung hukum yang memberikan perlindungan hukum terkait dengan pengelolaan keuangan negara untuk melaksanakan pembangunan sesuai rencana kerja pemerintah dan rencana pembangunan jangka menengah nasional (5 tahun). Untuk menyusun Anggaran Pendapatan dan Belanja Negara diatur dalam Konstitusi UUD 1945, pasal 23 ayat (1) Anggaran Pendapatan dan Belanja Negara seabagi wujud dari pengelolaan keuangan negara ditetapkan setiap tahun dengan undang-undang dan dilaksanakan secara terbuka dan bertanggung jawab untuk sebesar-besarnya kemakmuran rakyat, (2) Rancangan Undang-Undang Anggaran Pendapatan dan Belanja Negara diajukan oleh Presiden untuk dibahas bersama Dewan Perwakilan Rakyat dengan memperhatikan pertimbangan Dewan Perwakilan Daerah. Berkaitan dengan Keuangan Negara terbitlah Undang-Undang Nomor 17 Tahun 2003, dan Undang-Undang Nomor 1 Tahun 2004 Tentang Perbendaharaan Negara, ditindaklanjuti dengan terbitnya Peraturan Pemerintah Nomor 90 Tahun 2010 tentang Penyusunan Rencana Kerja dan Anggaran Kementerian Negara/Lembaga, dan teknis operasionalnya diterbitkan berbagai Peraturan Menteri Keuangan.

Dari yang telah diutarakan diatas, maka dari aspek instrumen implementasi dengan berbagai arah kebijakan dan instrumen teknis dimaksud, maka tidak ada lagi alasan politis dan teknis agar berbagai program dan kegiatan untuk mewujudkan kesejahteraan rakyat oleh pemerintah pusat dan daerah untuktidak dapat dilaksanakan dengan sebaikbaiknya.

Perlu diketahuni dari sisi alokasi APBN 2016, dana yang disediakan untuk pembangunan 
rakyat Indonesia ini sebesar Rp. 2.000 Triliun lebih dan tentunya digunakan untuk pembangunan diberbagai sektor oleh Pemerintah Pusat dan Daerah disamping untuk membayar utang pemerintah yang saat ini lebih dari sekitar Rp. 400 triliun, antara lain . Sektor Pendidikan sebesar $20 \%$ dari APBN, Sektor Kesehatan 5\% dari APBN, dan 10\% dari alokasi APBD masing-masing daerah. Alokasi subsidi besar untuk orang miskin (beras Raskin) sekitar 20 Triliun, alokasi pembangunan perumahan dan kawasan pemukiman oleh PUPR cukup besar untuk mengatasi kekurangan rumah sehat, bantuan cash transfer, dan schema-schema program lainnya yang sifatnya bantuan sosial, jaminan sosial, bantuan modal, dan lain sebagainya. Berikut ini adalah progres yang dicapai dengan dukungan anggaran yang cukup besar dan setiap tahun terus menaik, merupakan gambaran yang dapat kita nilai bersama sejauh mana tingkat efektifitas dan efisiensinya pelaksanaan program dan kegiatan yang dilakukan pemerintah.

\section{Penduduk}

Indonesia merupakan satu Negara dengan penduduk yang besar. Berdasarkan data PBB, Indonesia mendudukan urutan keempat setelah China, India dan Amerika Serikat. Saat ini jumlah penduduk Indonesia adalah 257,56 juta orang (3,50 \% dari total penduduk dunia), China dengan jumlah penduduk 1,38 miliar rang ( $18,72 \%$ dari total penduduk duna), India dengan jumlah penduduk 1,31 miliar ( $17,84 \%$ dari total penduduk dunia, dan Amerika denan jmlah penduduk 321,77 juta orang menempatkan pada proporsi $4,38 \%$ dari penduduk dunia.

Dari sisi komposisi penduduk terlihat bahwa jumlah penduduk usia produktif ( $15-64$ tahun) menunjukan adanya peningkatan setiap tahunnya, sementara itu jumlah penduduk tidak produktif usia 0-14 tahundan usia penduduk 65 tahun keata cenderung mengalami penurunan. Pada tahun 2011 komposisi penduduk usia 15-64 tahun sebesar $66,64 \%$ menjadi $67,28 \%$ pada tahun 2015 , sementera itu komposisi usia penduduk 0-14 tahun menurun dari $28,32 \%$ menjadi $27,35 \%$. Namun sebaliknya yang terjadi pada usia 65 tahun ke atas mengalami peningkatan dari $5,04 \%$ menjadi $5,37 \%$. hal tersebut menyebabkan angka beban ketergantungan penduduk Indoneia terus mengalami penrunan setiap tahunnya. Tercatat pada ahun 2011 angka beban ketergantungan penduduk sebesar 50,06 menurun menjadi 49,25\% pada tahun 2013 dan terus menurun hingga 2015 menjadi 48,63.

Angka beban ketergantungan pada tahun 2015 sebesar 48,63 berarti setiap 100 penduduk produktif menanggung 48,63 penduduk tidak produktif yang terdiri dari anak-anak dan lansia. Menurunnya angka beban ketergantungan juga dapat menggambarkan bahwa jumlah penduduk produktif yang semakin meningkat relative terhadap jumlah penduduk yang tidak produktif. Jika kecenderungan penurunan angka beban ketergantungan terus berlangsung, maka diharapkan Indonesia akan aegera mencapai fase ketika rasio ketergantungan mencapai titik terendah ( windows of opportunity). Persoalan Negara saat ini kalau kelompok usia produktif, tidak memberikan kontribusi produktifitas bagi pertumbuhan ekonomi, maka ini juga menjadi msibah demografi ( meningkatnya angka pengangguran, dan $\mathrm{PHK}$ ).

\section{Kesehatan dan Gizi.}

Tingkat kualitas kesehatan merupakan indicator penting untuk menggambarkan mutu pembangunan manusia suatu wilayah. Semakin sehat kndisi suatu masyarakat maka akan semakin mendukung proses dan dinamika pembangunan ekonomi suatu Negara/wilayah semakin baik. Pada akhirnya hasil dari kegiatan perekonomian adalah tingkat produktifitas penduduk suatu wilayah dapat diwujudkan berkaitan dengan pembangunan kesehatan, pemerintah melakukan berbagai program kesehatan untuk meningkatkan derajat kesehatan masyarakat khususnya memberikan kemudahan akses ;pelayanan publik, seperti Puskesmas yang sasaran utamanya menurunkan angka tingkat kesakitan masyarakat, menurunkan prevalensi gzi buruk dan gizi kurang serta meningkatkan angka harapan hidup.

\section{a. Pemanfaatan Fasilitas Tenaga Kesehatan}

Persentase balita yang kelahirannya ditolong tenaga kesehatan meningkat dari $86,66 \%$ pada tahun 2013 menjadi 87, 09\%, di tahun 2014 ( sedikit sekali hanya 0,43\%), . Sedangkan penolong persalinan dengan tenaga dukun bayi terutama dipedesaan , persentasenya terus menurun dari $22,48 \%$ pada tahun 2012, turun menjadi $19,34 \%$ pada tahun 2013, dan 17,48 \%pada tahun 2014 , tidak terlalu signikan penurunnya. Perubahan sikap masyarakat khususnya diperkotaan yang berobat ke praktek dokter/klinik tahun 2014 sebesar $35,33 \%$ penduduk, dan $26,83 \%$ yang 
berobat ke puskesmas. Walaupun persentase peningkatannya masih kecil sekitar $1 \mathrm{~s} / \mathrm{d}$ di bawah $1 \%$. Demikian juga angka rujukan meningkat dan pemanfaat RS untuk berobat menurun, dan pergi ke dukun bersalin memang menurun tapi dengan persentase yang kecil ( di bawah 1\%).

\section{Pendidikan}

Pemenuhan atas hak untuk mendapatkan pendidikan yang bermutu merupakan ukuran keadilan dan pemerataan atas hasil pembangunan dan sekaligus merupakan investasi sumber daya manusia yang diperlukan untuk mendukung keberlangsungan pembangunan. Pemerataan, akses dan peningkatan mutu pendidikan akan membuat warga negara Indonesia memiliki kecakapan dalam rangka pembangunan manusia seutuhnya. Dalam beberapa tahun kedepan pembangunan pendidikan nasional masih dihadapkan pada berbagai tantangan serius, terutama dalam upaya meningkatkan kinerja yang mencakup:

1. Pemerataan dan perluasan akses,

2. Peningkatan mutu, relevansi dan daya saing,

3. Penataan tata kelola, akuntabilitas, dan citra public,

4. Peningkatan pembiayaan.

Beberapa indicator output yang dapat menunjukkan kualitas pendidikan SDM antara lain: AMH (Angka Melek Huruf), Tingkat Pendidikan, APS (Angka Partisipasi Sekolah), APK (Angka Partisipasi Kasar), dan APM (Angka Partisipasi Murni). Indikator input pendidikan sala satunya adalah fasilitas pendidikan.

4. Ketenagakerjaan

Ketenagakerjaan merupakan salah satu masalah terbesar yang menjadi perhatian pemerintah, dimana masaalah ketenagakerjaan ini merupakan masaalah yang sangat sensitive yang harus diselesaikan dengan berbagai pendekatan agar masaalah tersebut tidak meluas yang berdampak pada penurunan kesejahteraan dan keamanan masyarakat. Berbagai masaalah dibidang ketenagakerjaan yang dihadapi pemerintah antara lain tingginya tingkat pengangguran, rendahnya perluasan kesempatan kerja yang terbuka, rendahnya kompetensi dan produktivitas tenaga kerja, serta masaalah pekerja anak. a. Tingkat Partisipasi Angkatan Kerja (TPAK) dan Tingkat Pengangguran Terbuka (TPT).

TPAK merupakan indicator ketenagakerjaan yang penting yang digunakan untuk menganalisa dan mengukur capaian hasil pembangunan. Selain itu TPAK juga merupakan indicator yang digunakan untuk mengukur jumlah besarnya angkatan kerja, yang merupakan rasio antara jumlah angkatan kerja dngan jumlah penduduk usia kerja (usia produktif 15 tahun keatas). TPAK pada kondisi bulan agustus 2014 di daerah perkotaan mengalami peningkatan sebesar $0,27 \%$ jika dibandingkan dengan kondisi yang sama tahun sebelumnya yaitu bulan agustus 2013, sedangkan di daerah perdesaan mengalami penurunan sebesar $0,62 \%$. TPAK secara nasional mengalami penurunan sebesar $0,17 \%$, yaitu dari $66,77 \%$ pada agustus 2013 menjadi 66,60\% pada agustus 2014. Penurunan TPAK ini merupakan indikasi menurunnya kecenderungan penduduk ekonomi aktif untuk mencari atau melakukan kegiatan ekonomi. Sementara pada februari 2015 TPAK Indonesia naik menjadi 69,50\% dari $69,17 \%$ pada februari 2014 . Tingkat pengangguran terbuka pada agustus 2014 diperkotaan terlihat lebih tinggi jika dibandingkan daerah perdesaan yaitu sebesar $7,12 \%$ berbanding $4,81 \%$. Lebih tingginya TPT di daerah perkotaan menunjukkan bahwa lapangan kerja yang tersedia diperkotaan belum mampu menyerap jumlah tenaga kerja dalam jumlah yang besar.

\section{b. Lapangan Usaha}

Distribusi penduduk yang bekerja menurut lapangan usaha pada dokumen ini dibagi menjadi 3 katagori lapangan usaha yaitu Pertanian ( pertanian, kehutanan, perburuan, dan perikanan), Industri ( pertambangan, dan penggalian, industri pengolahan, listrik, gas dan air serta bangunan/konstruksi), dan jasajasa ( perdagangan besar, eceran, rumah makan dan hotel, angkutan, pergudangan, komunikasi, asuransi, usaha persewaan bangunan, tanah dan jasa perusahaan, serta jasa kemasyarakatan).

\section{c. Upah/Gaji/Pendapatan bersih}

Upah/gaji merupakan imbalan yang diterima oleh pekerja atas jasa yang diberikan dalam proses memproduksi barang dan jasa dalam suatu instansi / perusahaan. Upah/gaji yang diterima oleh setiap pekerja digunakan untuk memenuhi kebutuhan sehari-hari baik untuk 
kebutuhan pribadi maupun untuk kebutuhan keluarga. Jika dilihat dari rata-rata upah/gaji/pendapatan bersiha dalam sebulan dilihat menurut pendidikan tertinggi yang ditamatkan secara umum terjadi peningkatan rata-rata sebesar 4,02\% pada agustus 2014 . Bila dibandingkan antara pekerja laki-laki dan pekerja perempuan, pada agustus 2014 ratarata upah/gaji pekerja perempuan mengalami peningkatan rata-rata lebih besar dibandingkan pekerja laki-laki yaitu sebesar $4,37 \%$, sementara pekerja laki-laki rata-rata mengalami peningkatan upah/gaji hanya sebesar 3,91\% dibandingkan kondisi yang sama tahun sebelumnya. Bila pada pekerja laki-laki maupun pekerja perempuan peningkatan tertinggi rata=rata upah/gaji menurut pendidikan terakhir yang ditamatkan justru berasal dari pekerja yang tidak / belum pernah sekolah yaitu sebesar 15,32\% dan 22,24\% pada agustus 2014. Peningkatan rata-rata upah/gaji berikutnya berasal dari pekerja yang tidak/belum tamat SD $(7,05 \%)$ dan pekerja dengan pendidikan tertinggi yang ditamatkan SD / Ibtidaiyah $(5,99 \%)$. Kondisi yang sama juga terjadi pada pekerja perempuan dimana rata-rata upah / gaji pekerja yang tidak / belum tamat SD $(16,24 \%)$ dan pekerja yang tamat SD / Ibtidaiyah (11,57\%) pada agustus 2014.

\section{d. Pekerja Anak ( usia 10 - 17 tahun).}

Keterlibatan anak dalam dunia kerja tidaklah terjadi dengan sendirinya, melainkan disebabkan oleh beberapa faktor, yaitu berasal dari dalam diri anak maupun karena pengaruh lingkungan terdekat, selain itu juga disebabkan karena faktor ekonomi, sosial, budaya dan faktor-faktor lain. Dari faktor ekonomi, kemiskinan keluarga menyebabkan tidak mampunya dalam memenuhi kebutuhan pokok. Kondisi ini menyebabkan anak dengan kesadaran sendiri atau dipaksa oleh keluarga untuk bekerja, sehingga kebutuhan pokoknya dapat terpenuhi dan membantu keluarga dalam mencari nafkah. Secara sosial ketidak harmonisan hubungan antar anggota keluarga dan pengaruh pergaulan dengan teman, merupakan faktor yang menyebabkan anak bekerja. ditempat bekerja merupakan tempat yang dapat dijadikan tempat bergantung bagi anak. Faktor budaya yang menyebabkan anak bekerja adalah adanya pandangan dsari sebagian masyarakat yang lebih menghargai anak yang bekerja. Mereka menganggap bahwa anak

\section{Taraf dan Pola Konsumsi}

Pola konsumsi penduduk juga merupakan salah satu indikator sosial ekonomi masyarakat yang sangat dipengaruhi oleh budaya dan lingkungan setempat. Budaya dan prilaku lingkungan akan membentuk pola kebiasaan tertentu pada kelompok masyarakat. Data pengeluaran dapat mengungkapkan pola konsumsi rumah tangga secara umum menggunakan indikator proporsi pengeluaran untuk makanan dan non makanan. Komposisi pengeluaran rumah tangga dapat dijadikan ukuran untuk menilai tingkat kesejahteraan ekonomi penduduk.

\section{Perumahan dan Lingkungan}

Rumah merupakan salah satu kebutuhan primer, kebutuhan yang paling mendasar yang tidak dapat dilepaskan dari kehidupan manusia sekaligus merupakan faktor penentu indikator kesejahteraan rakyat. Rumah selain sebagai tempat tinggal, juga dapat menunjukkan stratus sosial seseorang, yang berhubungan positif dengan kualitas / kondisi rumah. Selain itu rumah juga merupakan sarana pengamanan dan ketentraman hidup bagi manusia dan menyatu dengan lingkungannya. Kualitas lingkungan rumah tinggal meempengaruhi status kesehatan penghuninya.

\section{Kemiskinan}

Masalah kemiskinan merupakan persoalan pokok bangsa Indonesia yang selalu menjadi prioritas pemerintah dan menjadi agenda rutin dalam rencana pembangunan nasional.

a. Perkembangan penduduk miskin di Indonesia.

Secara umum, presentase penduduk miskin terhadap jumlah seluruh penduduk Indonesia menunjukkan tren menurun secara melambat selama periode 2012-2015. Tingkat penurunan kemiskinan yang hanya mencapai $0,3 \%$ pada tahun 2015 adalah yang terkecil sepajang periode 4 tahun terakhir. Pemerintah telah dapat menurunkan jumlah penduduk miskin dari 29,13 juta jiwa (11, 96\%) pada tahun 2012 menjadi 28,59 juta jiwa $(11,22 \%)$, pada Maret 2015. Meskipun menurun disbanding tahun 2012, tetapi sejak tahun 2013 jumlah penduduk miskin selalu meningkat setiap tahunnya. Di tahun 2015, jumlah penduduk miskin mengalami jumlah peningkatan sebanyak 310.000 jiwa dari tahun 2014 dan 520.000 jiwa dari tahun 2013. Peningkatan jumlah penduduk miskin karena meningkatkan harga beberapa komoditas bahan pokok dipasaran dan naiknya bahan bakar minyak 
selama 2 tahun terakhir. Data tahun 2015 menunjukkan jumlah penduduk miskin diperkotaan sebanyak 10,65 juta jiwa (8,29\%) dan diperdesaan sebanyak 17,94 juta jiwa ( $14,21 \%)$, angka ini meningkat dari tahun 2014. Berdasarkan data tersebut, pemerintah dapat lebih mengencarkan dalam merealisasikan program pengentasan kemiskinan terutama pada daerah perdesaan. Kondisi geografis Indonesia sebagai negara kepulauan membuat jumlah penduduk miskin tidak dapat dilihat pada satu titik tapi perlu dilihat pola persebaran. Selama periode 2013- 2015 secara umum penduduk miskin di setiap pulau mengalami penurunan. Penurunan terjadi di pulau Maluku dan Papua, yaitu sebesar 1,11\% pada tahun 2015. Meskipun cenderung mengalami penurunan pulau Bali dan Nusa Tenggara memperlihatkan kondisi sebaliknya, persentase penduduk miskin pada pulau ini naik $1.05 \%$ dari tahun sebelumnya. Dari segi jumlah, sebagian besar penduduk miskin masih berpusat di pulau jawa, yaitu sebanyak 15.450.000 orang pada tahun 2015. Namun dari segi persentase, persentase penduduk miskin terbesar berada di pulau Maluku dan Papua, yaitu sebesar 22,04\%. Kondisi ketimpangan kemiskinan antara dua pulau ini mengindikasi bahwa belum terwjudnya pemerataaan pembangunan diseluruh Indonesia. Selain GK, rata-rata kesenjangan pengeluaran masing-masing penduduk miskin terhadap garis kemiskinan perlu diperhatikan. Ukuran untuk mengur kesenjangan pengeluaran disebut sebagai Indeks Kedalaman Kemiskinan (IKK). Berdasarkan data nilai IKK mengalami peningkatan pada tahun 2015, dari 1,75 pada tahun 2014 menjadi 1,97. Peningkatan nilai IKK menunjukkan rata-rata pengeluaran penduduk miskin terhadap GK kemiskinan semakin jauh. Semakin besar nilai dari IKK berdampak pada semakin sulit penduduk miskin untuk keluar dari kemiskinan atau terjebak dalam kemiskinan yang terlalu dalam. Jika ditinjau dari daerah tempat tinggal, nilai IKK perdesaan lebih tinggi dari perkotaan. Ini menunjukkan bahwa penduduk perdesaan lebih banyak terjebak dalam kondisi miskin "terlalu dalam" dibandingkan daerah perkotaan.

\section{b. Karakteristik Rumah Tangga Miskin Indonesia}

Karakteristik rumah tangga miskin dapat dilihat dari kondisi Sosial demografi, pendiikan dan ketenagakerjaan dari kepala rumah tangga, serta kondisi perumahan. Pemahaman mengenai karakteristik rumah tangga miskin penting sebagai dasar dalam penyusunan kebijakan dan program pengentasan kemiskinan agar tepat sasaran. Selain itu, informasi mengenai karakteristik rumah tangga miskin juga dapat digunakan untuk mengindikasi penyebab kemiskinan secara tidak langsung.

\section{c. Rasio Gini}

Rasio Gini atau koefisien adalah alat mengukur derajat ketidakmerataan atau ketimpangan agregat (secara keseluruhan) yang angkanya berkisar antara nol (pemeretaan sempurna) hingga satu ( ketimpangan yang sempurna). Dapat dikatakan bahwa suatu distribusi pendapatan semakin merata jika nilai koefisien mendekati nol. Sebaliknya distribusi pendapatan dikatakan makin tidak merata jika nilai Koefisien Gininya makin mendekati satu. Indonesia dengan Rasio Gini 0,41 sudah pada posisi ketimpangan yang cukup lebar. Rasio Gini ini menaik terus sejak 1996 dari angka 0,36, meningkat pada angka 0,41 tahun 2011, dan bertahan terus pada angka tersebut sampai tahun 2015.

\section{Penutup}

Dari hasil penelitian dan pembahasan di atas maka dapat ditarik simpulan sebagai berikut:

1. Kebijakan Pemerintah sebagai suatu kebijakan publik merupakan kebijakan yang menjadi wewenang pemerintah dan diberikan Negara sesuai dengan amanat Konstitusi.

2. Untuk melaksanakan kebijakan dimaksud, pemerintah telah diberikan alat kelengkapan untuk mengeksekusi kebijakan, baik dalam bentuk dukungan anggaran, perangkat pemaksa, sumber daya manusia, instrumen hukum, pengelolaan sumber daya alam, yang dilaksanakan sesuai dengan peraturan perundang-undangan.

3. Untuk melaksanakan kebijakan pemerintah, telah disusun sistem perencanaan yang komprehensif dengan memperhatikan kemampuan ekonomi makro, dan kemampuan fiskal Negara.

4. Telah disusun Rencana Pembangunan Menengah Nasional siklus 5 tahunan dan Rencana Kerja Pemerintah dan Rencana Strategis Kementerian / Lembaga untuk melaksanakan Konstitusi yaitu terwujudnya Negara Kesejateraan.

5. Berbagai indikator Kesejahteraan telah dirumuskan oleh Badan Pusat Statistik sebagai lembaga pemerintah yang 
kredibel, dan terlihat progress yang telah dicapai untuk mewujudkan Negara Kesejahteraan.

6. Hasilnya menunjukkan ada peningkatan, namun lambat dan kurang signikan jika dibandingkan dengan dukungan anggaran belanja yang disediakan pemerintah.

7. Masih tingginya angka kemiskinan $11,22 \%$ dengan Gino rasio 0,41 merupakan indikasi bahwa tingginya angka kemiskian tersebut ( sekitar 28 juta jiwa), dikuti kesenjangan pendapatan yang semakin lebar, untuk terjadinya (pemicu) masalah sosial, konflik sosial dan kerawanan-kerawanan yang akan melebar ke wilayah politik, dan integritas NKRI.

\section{Daftar Pustaka}

Arifin Ali, Andi Syamsu Alam, Kebijakan Publik dan Transparansi Penyelenggaraan Pemerintah Daerah,Alfabeta, 2014

Faried Ali, Andi Syamsu Alam, Studi Kebijakan Pemerintah, Jakarta, 2016

Hadi Wahono, Negara Kesejahteraan, solusindo, Jakarta, 2015

Kevin Dayoh, Karakteristik dan asas Pemerintah yang baik, Jakarta 2013 